\title{
Conformational Changes in DNA upon Ligand Binding Monitored by Circular Dichroism
}

\author{
Yu-Ming Chang ${ }^{1}$, Cammy K.-M. Chen ${ }^{1}$ and Ming-Hon Hou ${ }^{2, *}$ \\ 1 Institute of Biological Chemistry, Academia Sinica, Taipei 115, Taiwan; \\ E-Mails: stanley039@yahoo.com.tw (Y.-M.C.); cammychuang@ hotmail.com (C.K.-M.C.) \\ 2 Institute of Genomics and Bioinformatics, National Chung Hsing University, Taichung 402, Taiwan \\ * Author to whom correspondence should be addressed; E-Mail: mhho@ @chu.edu.tw; \\ Tel.: +886-4-2284-0338 (ext. 7011); Fax: +886-4-2285-9329.
}

Received: 21 January 2012; in revised form: 22 February 2012 / Accepted: 24 February 2012 /

Published: 12 March 2012

\begin{abstract}
Circular dichroism (CD) spectroscopy is an optical technique that measures the difference in the absorption of left and right circularly polarized light. This technique has been widely employed in the studies of nucleic acids structures and the use of it to monitor conformational polymorphism of DNA has grown tremendously in the past few decades. DNA may undergo conformational changes to B-form, A-form, Z-form, quadruplexes, triplexes and other structures as a result of the binding process to different compounds. Here we review the recent CD spectroscopic studies of the induction of DNA conformational changes by different ligands, which includes metal derivative complex of aureolic family drugs, actinomycin D, neomycin, cisplatin, and polyamine. It is clear that CD spectroscopy is extremely sensitive and relatively inexpensive, as compared with other techniques. These studies show that CD spectroscopy is a powerful technique to monitor DNA conformational changes resulting from drug binding and also shows its potential to be a drug-screening platform in the future.
\end{abstract}

Keywords: DNA structure; circular dichroism; conformational changes; DNA-binding drugs; thermodynamic parameters 


\section{Introduction}

Circular dichroism (CD) spectroscopy is an optical technique that measures the difference in the absorption of left and right circularly polarized light [1]. This phenomenon originated from the absorption of optically active chiral molecules. CD spectroscopy is very sensitive to the secondary structure of polypeptides and proteins and thus has been employed in many different fields, such as investigation of the proteins' secondary structure and spectral studies of DNA [2-5]. Recently, the structures of small organic molecules such as oligo-peptides and oligo-nucleotides have been studied with this technique with 180-300 nm ultraviolet light range [6-9].

Structural information on the oligo-nucleotides at atomic level cannot be provided by CD spectroscopy because the theoretical description is very complex [10]. However, CD spectroscopy offers significant cost and sensitivity advantages when compared with other analysis methods. (i) CD measurement is inexpensive, fast and allows comparative studies of related oligo-nucleotides in various conditions; (ii) We could easily titrate oligo-nucleotides with various agents such as acids, salts, alcohols, drugs and compounds to induce DNA conformational isomerizations; (iii) CD spectroscopy can be used to study oligo-nucleotides as well as longer DNA fragments with a 3000-8000 base pair [11]; (iv) $\mathrm{CD}$ can be used to make correlations between X-ray diffraction and infrared spectroscopy because it can analyze not only in solutions but also in films [12]; (v) CD shows extreme sensitivity for low concentrations of DNA (20 $\mu \mathrm{g} / \mathrm{mL})$. In addition, CD shows very high sensitivity (it is possible to detect as little as $25 \mu$ g oligonucleotides) which made it a useful method for study low solubility samples.

NMR, X-ray diffraction and other conformational analysis methods have many disadvantages, such as the need for large amounts of oligo-nucleotides, short length of DNA molecules, limited experimental conditions (in solution or crystallization form) and a single discrete structure instead of a mixture of isomerizing conformers. Knowing the advantages and disadvantages of different analysis methods, $\mathrm{CD}$ is considered to be one of the easiest and convenient methods designed to study the secondary structure of DNA.

Over the last three decades, enormous advances and efforts have been focused on ligand-DNA interactions. The study of ligand-DNA interactions is critical for a complete understanding of replication and transcription processes, which are attractive targets for the rational design of anticancer and antibiotic drugs. Most chemotherapeutic anticancer drugs currently used come from or are derived from DNA-binding ligands which interact with the DNA duplex by three general binding modes: DNA intercalation, groove binding and covalent binding [13]. DNA interacting drugs exhibit cytotoxic activity to tumor cell through preventing DNA relaxation, blocking gene expression and inhibiting DNA replication. The importance of discovering and designing DNA interacting drug is undisputable. The study of drug-DNA interactions and the mechanisms of drug action is highly important for drug discovery of more efficient and specifically-targeted drugs with fewer side effects [14]. In this review, we summarized the studies of CD spectra, monitoring DNA conformational change upon treatment with several DNA-binding ligands, such as the metal derivative complex of aureolic family drugs, actinomycin D (ActD), cisplatin and polyamines. 


\section{Conformational Polymorphism of DNA and DNA-Drug Complexes Monitored by CD}

\subsection{DNA (B-form, A-form, Z-form and Quadruplexes)}

In the most common double helical structure, right-handed B-DNA, the helix makes a turn every $3.4 \mathrm{~nm}$. There are about 10 base pairs per turn and $+36^{\circ}$ rotation per base pair [15]. The long wavelength CD spectrum of the sequentially heterogeneous DNA is conservative, but the CD spectra of synthetic oligo-nucleotides are depended on the primary sequence. B-form oligo-nucleotides are characterized by a positive long wavelength band at about 260-280 $\mathrm{nm}$ and a negative band around $245 \mathrm{~nm}$. However, the position and amplitude of the CD bands show markedly differences in terms of sequence diversity [16-18].

A-DNA is $\alpha$-helical double helix (right-handed) fairly similar to the B-DNA form, but with a shorter and more compact helical structure. A-DNA occurs only in dehydrated samples and favors low water conditions such as found in aqueous ethanol [19]. However, the slight increase in the number of base pairs per rotation and the smaller rise/turn of A-DNA compared to B-DNA results in a deepening of the major groove and preventing access by proteins. The CD spectrum of poly[d(G)].poly[d(C)] is similar to that of the true A-form DNA and is characterized by a dominant positive band at $260 \mathrm{~nm}$ and a negative band at $210 \mathrm{~nm}[18,20]$.

Z-form DNA is a left-handed helix with a zigzag phosphate backbone and shows only little difference in width of major and minor grooves. Formation of this structure is generally unfavorable, although certain conditions can promote it: by raising negative super helical stress or under low salt conditions of the molecule rich in purine-pyrimidine sequences [21]. The CD spectrum of Z-form DNA shows an inversion of the CD spectrum of the B-form, and it contains a negative band at about $290 \mathrm{~nm}$, a positive band around $260 \mathrm{~nm}$, and extremely deep negative band at $205 \mathrm{~nm}$ [22,23].

Self-complemented guanine-rich oligonucleotides (GROs) are found in many telomeric repeat sequences, and the G-quadruplex DNA has been constructed from quadruple strands of GROs with a building around tetrads of hydrogen-bonded guanine bases. There are two different types of G-quadruplexes; the spectra of parallel G-quadruplex has a dominant positive band at $260 \mathrm{~nm}$, whereas the spectra of anti-parallel G-quadruplex has a negative band at $260 \mathrm{~nm}$ and positive band at $290 \mathrm{~nm}$ [24,25]. Moreover, both of them have an additional characteristic positive peak at $210 \mathrm{~nm}$ [26].

\subsection{Chromomycin $A_{3}$ (Chro)}

The anticancer antibiotic chromomycin $\mathrm{A}_{3}$ (Chro), a DNA minor groove binding drug which interferes with replication and transcription is a member of the aureolic family of drugs isolated from Streptomyces griseus [27-29]. This drug contains di- and trisaccharide moieties connected to a $\beta$-ketophenol chromophore via $O$-glycosidic bonds disposed in a 2, 6 relationship about the anthracene ring, with the disaccharide at the two position and the trisaccharide attached at the 6 position (Figure 1). Chromomycin has been used for the treatment of malignant diseases, such as malignancy-associated hypercalcemia and testicular cancer [30]. 
Figure 1. The chemical structure of chromomycin $A_{3}$ (Chro). The oxygen atoms that coordinate the metal ion are shaded.

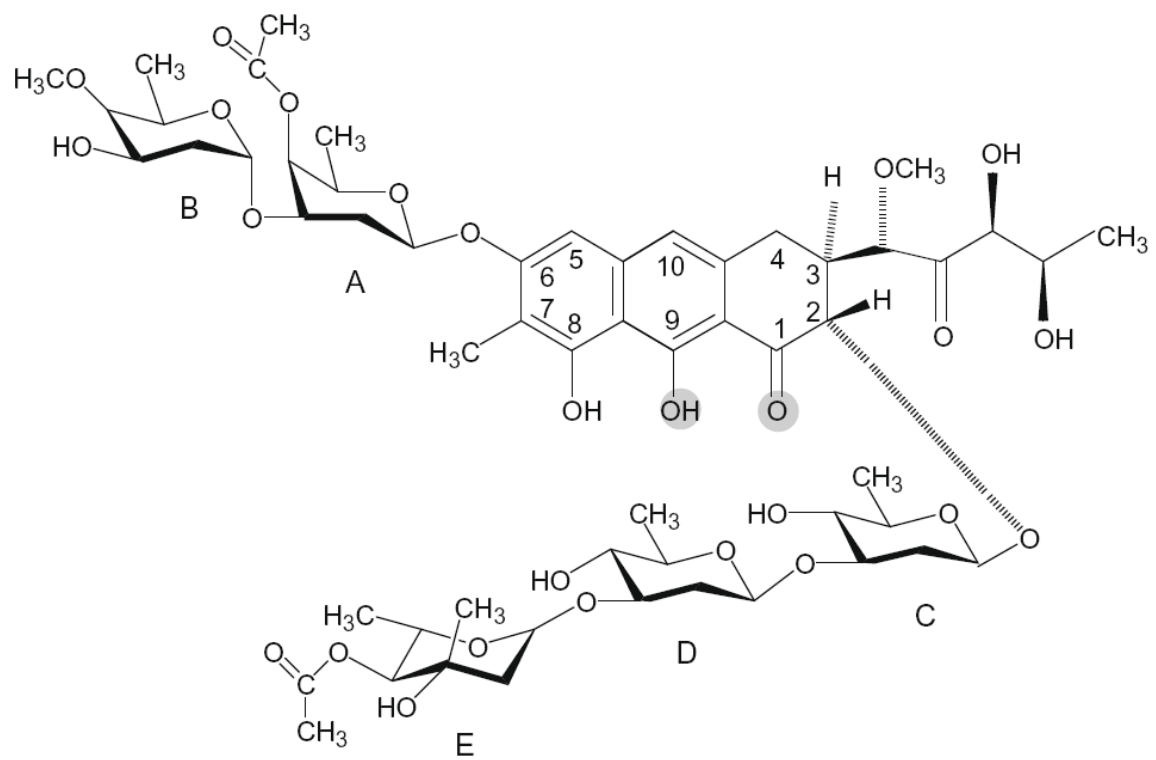

Previous optical spectroscopy and structural studies have shown that divalent metal ions, such as $\mathrm{Mg}^{2+}, \mathrm{Fe}^{2+}$, or $\mathrm{Co}^{2+}$, are required for Chro to bind to GC-rich oligonucleotide duplexes that are at least three base pairs long [31-33]. The metal ion alternation to influence the effect of aureolic family drugs in disease therapy has been discussed. Previous studies have reported that Chro is capable of forming a dimeric complex via chelation with $\mathrm{Fe}^{2+}$ in the absence of DNA. To explore the conformational changes of hairpin DNA duplexes upon binding to the $\left[(\mathrm{Chro})_{2}-\mathrm{Fe}^{2+}\right]$ complex, DNA conformations were monitored in the absence or presence of the $\left[(\mathrm{Chro})_{2}-\mathrm{Fe}^{2+}\right]$ complex using $\mathrm{CD}$ spectroscopy. The DNA tested here form self-complementary hairpin duplexes by using trinucleotides, 5'-TGT-3', as a loop region. In addition, their stem regions were identical, except for the central portion of four paired nucleotides that have central 2 base-paired (bp) G-tract with directions of either 5'-GC-3' or 5'-CG-3' flanked by $\mathrm{G}$ and $\mathrm{C}$, i.e., 4 bp G-tract (or A and T, i.e., 2 bp G-tract flanked by A and T). Previously, we have showed that the conformation of $\left[(\mathrm{Chro})_{2}-\mathrm{Mg}^{2+}\right]$ remains basically unchanged with and without DNA. Therefore, in the CD spectra of hairpin DNA duplexes complexed to $\left[(\mathrm{Chro})_{2}-\mathrm{Fe}^{2+}\right]$, the $\mathrm{CD}$ spectra of the $\left[(\mathrm{Chro})_{2}-\mathrm{Fe}^{2+}\right]$ complex were all subtracted to minimize the interference from $\left[(\mathrm{Chro})_{2}-\mathrm{Fe}^{2+}\right]$. In Figure $2 \mathrm{~A}$, the same profiles were observed for the CD spectra of the hairpin DNA duplexes containing regions of $4 \mathrm{bp}$ G-tract. The CD spectra are similar to typical B-DNA, which showed a band of negative and positive peaks at 250 and $280 \mathrm{~nm}$, respectively [34]. An increase in the CD spectra intensity at $\sim 220$ and $280 \mathrm{~nm}$ in all hairpin DNA duplexes containing regions of $4 \mathrm{bp}$ $\mathrm{G}$-tract is observed with the presence of $\left[(\mathrm{Chro})_{2}-\mathrm{Fe}^{2+}\right]$ complex (Figure 2B). Furthermore, DNA duplex GGCC exhibits the largest change in CD intensity at $280 \mathrm{~nm}$ and a smaller peak at $265 \mathrm{~nm}$ in the presence of the $\left[(\mathrm{Chro})_{2}-\mathrm{Fe}^{2+}\right]$ complex, which are similar to the A-DNA profile. 
Figure 2. (A) CD spectra of hairpin DNA duplexes including GGCC, CGCG, GCGC and CCGG in $25 \mathrm{mM}$ Tris- $\mathrm{HCl}$ buffer at $\mathrm{pH} 7.3$ with $50 \mathrm{mM} \mathrm{NaCl}$ at $25^{\circ} \mathrm{C}$. The concentration of DNA was $20 \mu \mathrm{M}$; (B) Normalized sum of the CD spectra of the [(Chro $\left.)_{2}-\mathrm{Fe}^{2+}\right]$-hairpin DNA duplex including GGCC, CGCG, GCGC, and CCGG minus [(Chro $\left.)_{2}-\mathrm{Fe}^{2+}\right]$ dimer in $25 \mathrm{mM}$ Tris- $\mathrm{HCl}$ buffer at $\mathrm{pH} 7.3$ with $50 \mathrm{mM} \mathrm{NaCl}$ at $25{ }^{\circ} \mathrm{C}$ [34]. Reprinted with permission from ref. [34]. (Copyright 2008, American Chemical Society)

A

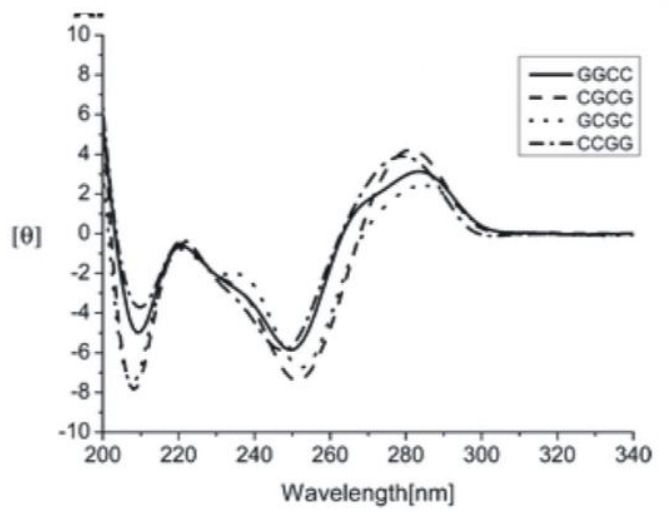

B

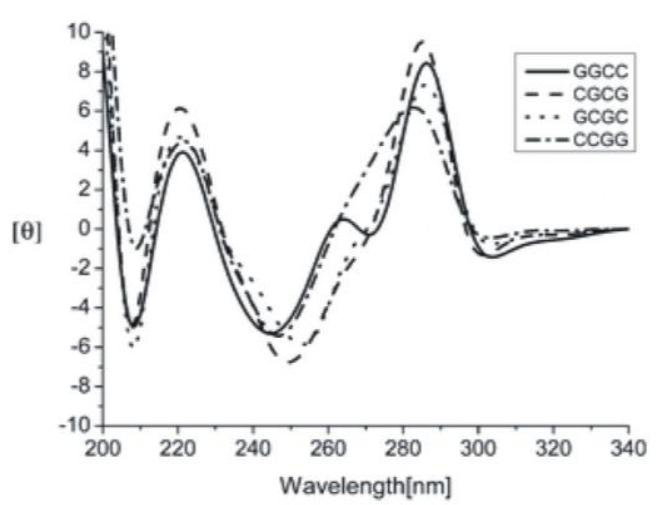

Circular dichroism was also used to measure the interactions between hairpin DNA duplexes that contains regions of 2 bp G-tract flanked by $\mathrm{A}$ and $\mathrm{T}$ and $\left[(\mathrm{Chro})_{2}-\mathrm{Fe}^{2+}\right]$ [34]. Results of CD measurements revealed only slight peak height differences at $\sim 220$ and $280 \mathrm{~nm}$ between the DNA duplex with/without the treatment of $\left[(\mathrm{Chro})_{2}-\mathrm{Fe}^{2+}\right]$ (parts A and B of Figure 3), suggesting subtle structural differences between the two. This is basically consistent with the previous observation that hairpin DNA duplexes containing regions of $2 \mathrm{bp}$ G-tract flanked by A and $\mathrm{T}$ exhibited lower equilibrium constants $\left(K_{\mathrm{a}}\right)$ upon binding to $\left.\left[(\mathrm{Chro})_{2}-\mathrm{Fe}^{2+} \text {. In addition, upon binding to [(Chro }\right)_{2}-\mathrm{Fe}^{2+}\right]$, the CD spectra of AGCT and ACGT were shifted toward longer wavelengths ( 275-280 nm), suggesting a slightly different binding mode.

Figure 3. (A) CD spectra of hairpin DNA duplexes including AGCT, ACGT, TGCA, and TCGA. The concentration of DNA was $20 \mu \mathrm{M}$; (B) Normalized sum of the CD spectrum of the $\left[(\mathrm{Chro})_{2}-\mathrm{Fe}^{2+}\right]$-hairpin DNA duplex including AGCT, ACGT, TGCA, and TCGA minus [(Chro $)_{2}-\mathrm{Fe}^{2+}$ ] dimer in $25 \mathrm{mM}$ Tris- $\mathrm{HCl}$ buffer at $\mathrm{pH} 7.3$ with $50 \mathrm{mM} \mathrm{NaCl}$ at $25{ }^{\circ} \mathrm{C}$ [34]. Reprinted with permission from ref. [34]. (Copyright 2008, American Chemical Society)

A

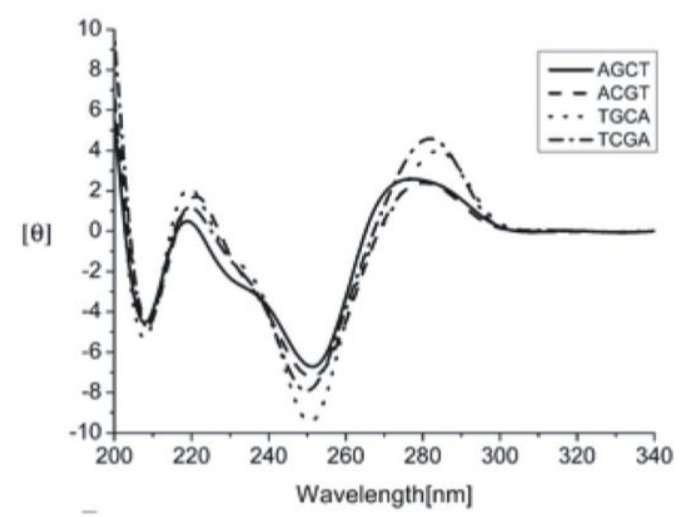

B

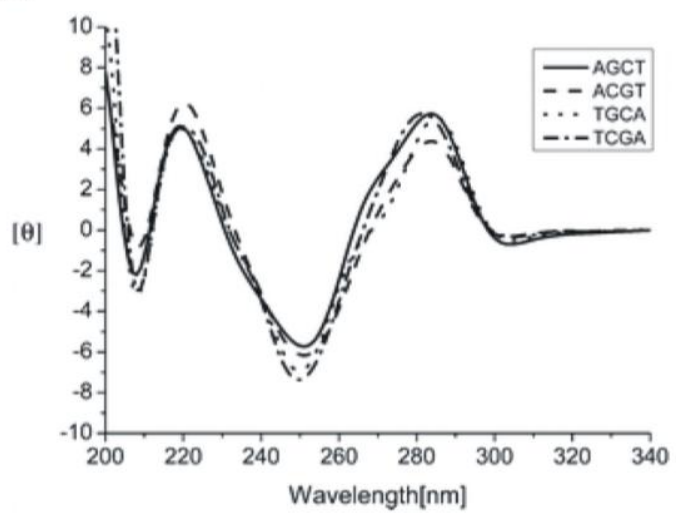




\subsection{Mithramycin (Mith)}

The anticancer antibiotic Mithramycin (Mith) is an RNA synthesis inhibitor and belongs to the aureolic family isolated from S. griseus [35]. Mith consists of aglycone ring, a chromomycinone moiety, and sugar residues connected to its either side by $O$-glycosidic bonds (Figure 4). Mith is a DNA-binding antitumor agent that inhibits tumor cell replication and transcription [36,37]. It is currently used in multiple areas of research, several cancer therapies and Paget's disease [28,38,39]. Recently, Fibach et al. [40] revealed that Mith is a potent inducer of fetal hemoglobin production in normal and thalassemic human erythroid precursor cells, and suggested that Mith may be used as a therapeutic agent in certain neoplastic diseases.

Figure 4. Chemical structure of mithramycin (Mith).

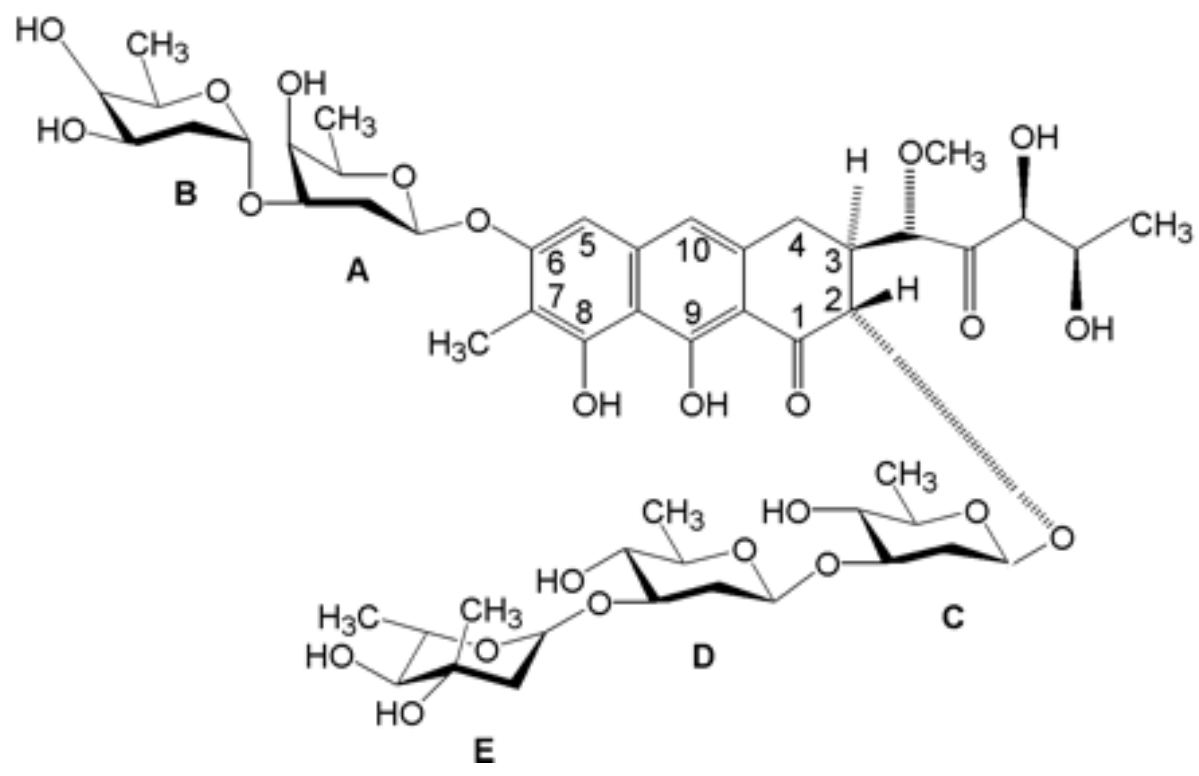

Mithramycin forms a stable dimeric complex by chelating with $\mathrm{Fe}(\mathrm{II})$. The structural effects of the $\left[(\mathrm{Mith})_{2}-\mathrm{Fe}^{2+}\right]$ complex on the conformation change of d(TTGGCCAA $)_{2}$ DNA duplex has been characterized using $\mathrm{CD}$ analyses [41]. As shown in Figure 5, the CD spectra of the [(Mith $)_{2}-\mathrm{Fe}^{2+}$ ] complex exhibit negative and positive peak intensities at 275 and $300 \mathrm{~nm}$, whereas the CD spectra of d(TTGGCCAA $)_{2}$ show a similar profile with B-DNA which have a band with negative and positive peaks around 250 and $280 \mathrm{~nm}$. The CD spectra of Mith and DNA signals overlap in the 200-300 nm regions. In addition, the $\mathrm{CD}$ spectra of $\left[(\mathrm{Mith})_{2}-\mathrm{Fe}^{2+}\right]-\mathrm{d}(\mathrm{TTGGCCAA})_{2}$ complex show a higher $\mathrm{CD}$ intensity at 287 and $275 \mathrm{~nm}$ when compared with the CD spectra sum of the [(Mith $)_{2}-\mathrm{Fe}^{2+}$ ] complex plus d(TTGGCCAA) 2 , resulting from a strong exciton-type couplet. It could be used as evidence for the relative binding affinities of the $\left[(\mathrm{Mith})_{2}-\mathrm{Fe}^{2+}\right]$ complex toward this DNA oligomer duplex. 
Figure 5. Comparison of the $\mathrm{CD}$ spectra of the $\left[(\mathrm{Mith})_{2}-\mathrm{Fe}^{+2}\right]$ complex, d(TTGGCCAA $)_{2}$, $\left[(\mathrm{Mith})_{2}-\mathrm{Fe}^{+2}\right]-\mathrm{d}(\mathrm{TTGGCCAA})_{2}$ complex and the sum of the CD spectra of [(Mith $\left.)_{2}-\mathrm{Fe}^{+2}\right]$ plus d(TTGGCCAA) $)_{2}$ in $20 \mathrm{mM}$ sodium-cacodylate buffer at $\mathrm{pH} 7.3$ with $100 \mathrm{mM} \mathrm{NaCl}$ at $25^{\circ} \mathrm{C}$. This figure was adapted from M.-H. Hou et al. [41] with permission.

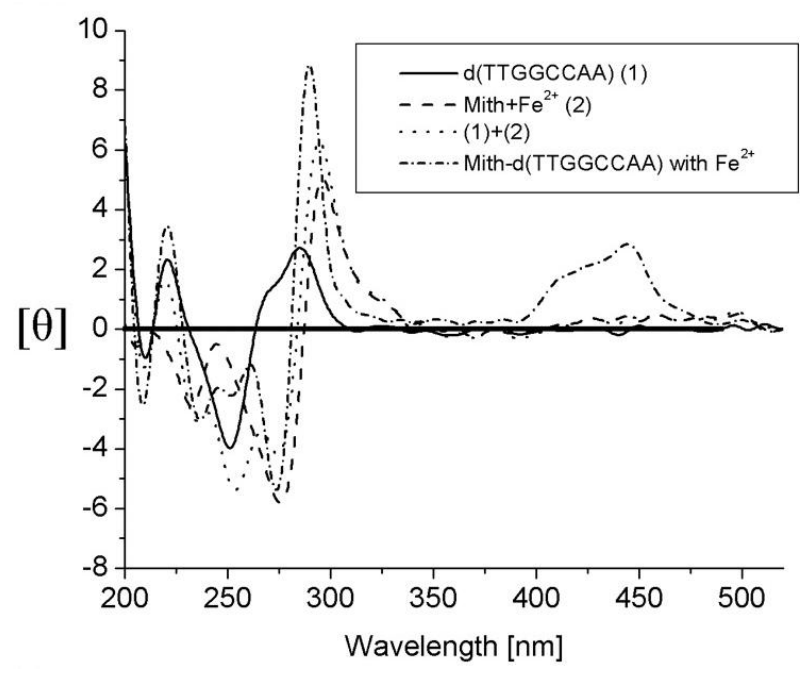

\subsection{Actinomycin D (ActD)}

Actinomycin D (ActD) (Figure 6) is a potent anticancer drug which binds to DNA by intercalating its phenoxazone ring at a GpC step with the two cyclic pentapeptides of the drug located in the DNA minor groove [42,43], thereby interfering with replication and transcription [44,45]. ActD binds specifically to the $\mathrm{GpC}$ sequence [46] by forming strong hydrogen bonds between the $\mathrm{NH} / \mathrm{C}=\mathrm{O}$ groups of threonines of ActD and the corresponding N3/N2 sites of adjacent guanine bases of the GpC step. Interestingly, many $\mathrm{GpC}$ binding sites are formed when the $(\mathrm{CTG})_{\mathrm{n}}$ triplet sequence adopts a hairpin arm (as part of a cruciform) or duplex form, but with alternating T:T mispairs. Studies on the properties of ActD and their interaction with DNA are significantly important in developing new drugs because CTG/CAG triplet repeat expansions (TREs) within genes are associated with various neurological diseases, including Huntington's disease, myotonic dystrophy, spinocerebellar ataxia and spinal and bulbar muscular atrophy [47-49].

Figure 6. Chemical structure of ActD. The cyclic pentapeptide attached to the quinonoid ring and the benzenoid ring of the phenoxazone group are labeled $\alpha$ and $\beta$, respectively.

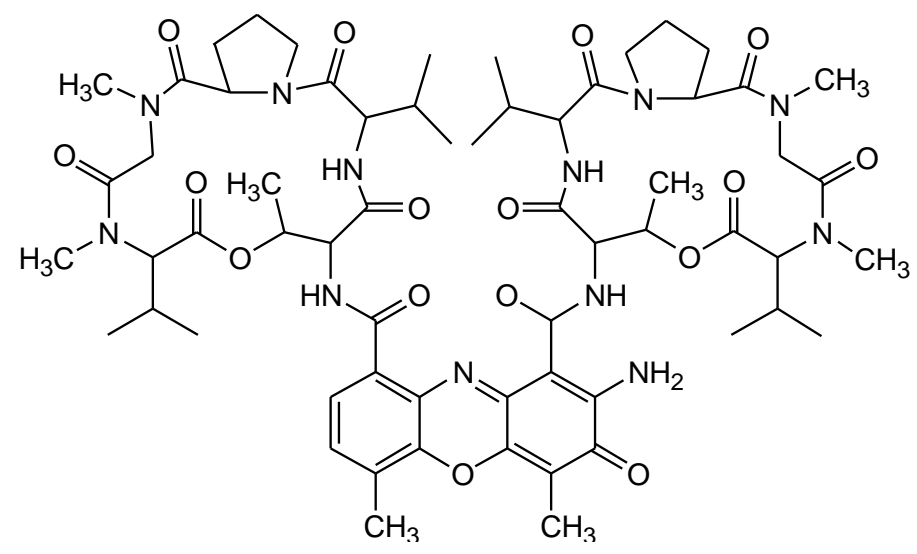


Figure 7A shows the CD spectra of DNA duplexes with AT0, AT1 and TT1 in the absence (top) and presence (bottom) of ActD, respectively [50]. The spectral changes observed for the ActD-DNA complexes showed a red shift from 275 to $290 \mathrm{~nm}$, due to a A-type DNA transition upon ActD

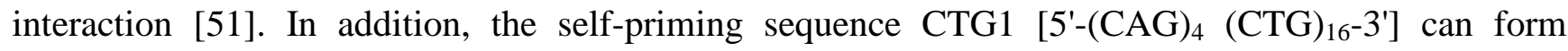
intra-strand hairpins consisting of both normal and mismatched base pairs, which promote primer-template slippage during DNA replication. The CD spectra of CTG1 showed concomitant increased peak intensity in the presence of $10 \mu \mathrm{M}$ ActD (Figure 7B). It suggests that conformational changes of long CTG repeats as well as increased stability are induced upon addition of ActD.

Figure 7. (A) CD spectra of AT0, AT1 and TT1 $(4 \mu \mathrm{M})$ in standard buffer alone (top) and with $10 \mu \mathrm{M}$ ActD are graphed (bottom). The CD spectra of ActD-DNA complexes were obtained by subtracting the spectrum of ActD, and DNA duplexes used in this study and include AT0, AT1 and TT1 (rectangles represent the binding sites for the phenoxazone ring of ActD); (B) CD spectra of CTG1 $(1 \mu \mathrm{M})$ in the same buffer solution. The CD spectra of ActD-DNA complexes were obtained by subtracting the spectrum of ActD alone. This figure was adapted from M.-H. Hou et al. [50] with permission.

A

\section{$\mathbf{A}$}
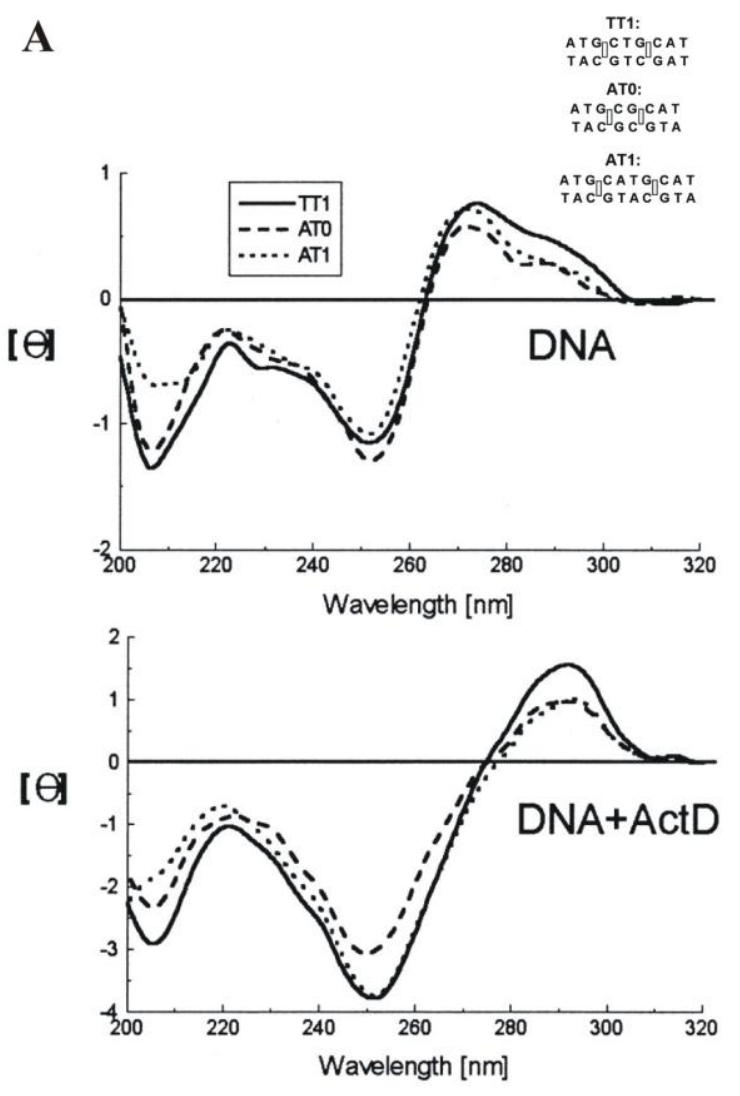

B

..... CTG1

$---\mathrm{CTG} 1+1.0 \mathrm{mMMgCl} 2$ -.-. CTG1 + $4.0 \mu \mathrm{MACtD}$ - CTG1 + $10 \mu \mathrm{MActD}$

[ $\theta$ ]

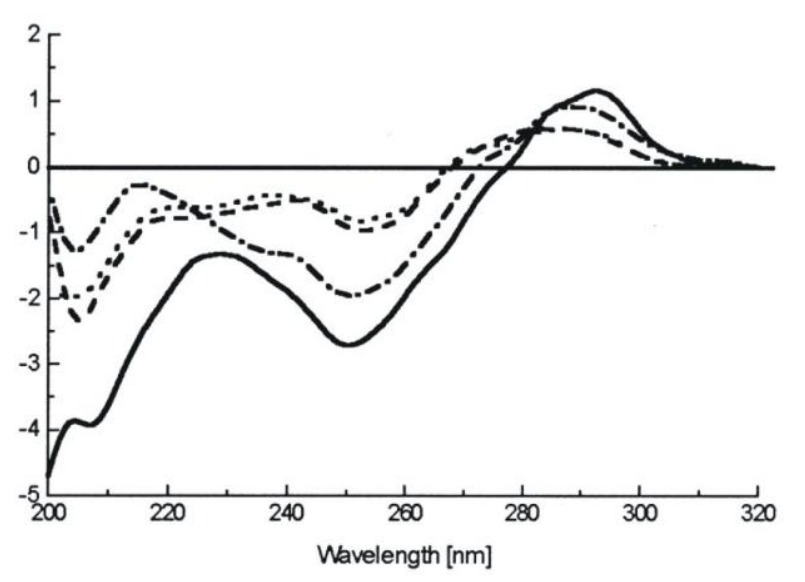

\subsection{Polyamines}

Polyamines are ubiquitous polycationic compounds, including spare aliphatic polycationic compounds, and they possess multiple positive charges (two for putrescine, three for spermidine and four for spermine) at physiological $\mathrm{pH}$ due to the protonations of their amine groups. Polyamines and the analogues are almost exclusively bound to DNA [52] or RNA [53-55] and are essential regulators 
of cell growth and gene expression as well as mitosis and meiosis [56]. Information collected recently has shown that polyamines affect protein-DNA interaction [57,58] and modulate the transcription of various genes $[59,60]$. In some tumor cells, polyamines are regulated poorly, resulting in higher polyamine concentrations than those in normal cells [56]. Furthermore, polyamines are essential materials for catenation of supercoiled DNA by topoisomerase [61,62]. The interaction between polyamines with nucleic acids induces the transition of B-DNA to A-DNA or Z-DNA depending on the conditions [63-65]. In summary, polyamines play important roles in a variety of biological process [56], thus numerous studies on the function of polyamines have been published.

Figure 8B and $\mathrm{C}$ show the CD spectra of DNA duplexes with normal (P1) and abnormal (M1 and B1) sequences in the presence of spermidine and spermine, respectively. As previous described, DNA duplexes (P1, M1 and B1) have a split peak which includes a large positive peak at $280 \mathrm{~nm}$ and a weak positive peak at $260 \mathrm{~nm}$ in the region of $260-290 \mathrm{~nm}$ of the spectrum similar to the $(A)_{n} \cdot(T)_{n}$ sequence [66]. In Figure 8B,C, a band with negative and positive peaks around 245 and $280 \mathrm{~nm}$ have been observed for the P1, M1, and B1 CD spectra, which is typical of B-DNA [67] and suggests that DNA duplexes remain as B-DNA conformation. However, addition of spermine causes a decrease in the intensity of both M1 and B1, and to a lesser extent P1 in the region of 240-250 nm.

Figure 8. (A) DNA duplexes used in the study of polyamines include P1 (a perfect duplex), B1 (a bulged loop duplex), M1 (a mismatched duplex), H1, H2 and H3 (hairpin duplexes); (B)(C) CD spectra of P1 (solid line), B1 (dotted line) and M1 (broken line) in solution of $20 \mathrm{mM}$ Tris-HCl buffer at $\mathrm{pH} 7.3$ with $5 \mathrm{mM}(\mathbf{B})$ spermidine or $(\mathbf{C})$ spermine at $10{ }^{\circ} \mathrm{C}$; (D) $\mathrm{CD}$ spectra of $\mathrm{H} 1$ (solid line), $\mathrm{H} 2$ (broken line) and $\mathrm{H} 3$ (dotted line) in $20 \mathrm{mM}$ Tris- $\mathrm{HCl}$ buffer at $\mathrm{pH} 7.3$ with $5 \mathrm{mM}$ spermine at $10{ }^{\circ} \mathrm{C}$. This figure was adapted from M.-H. Hou et al. [51] with permission.

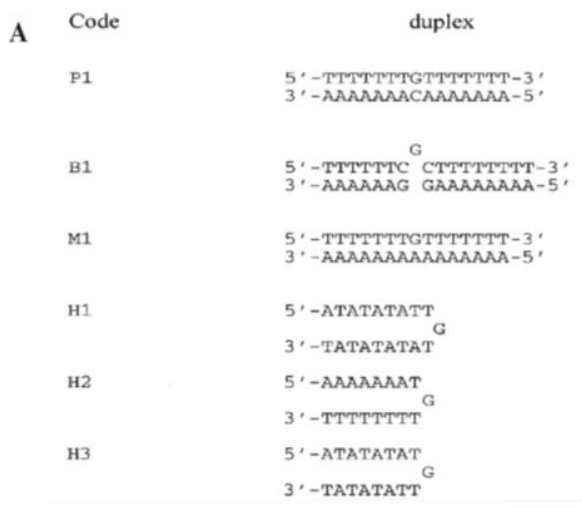

C

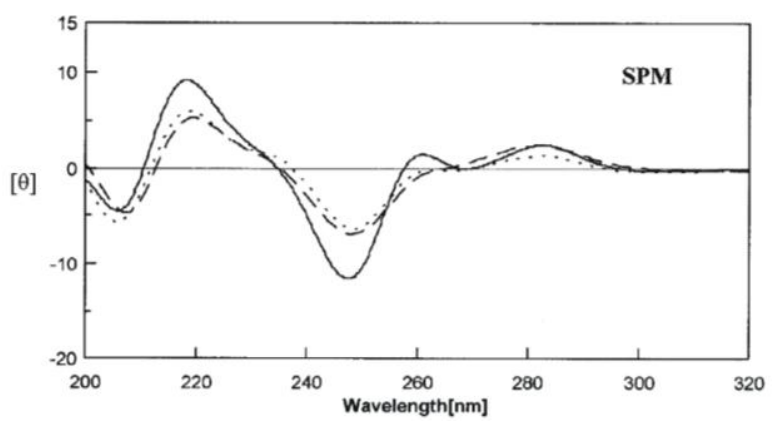

B

[ㅂ]

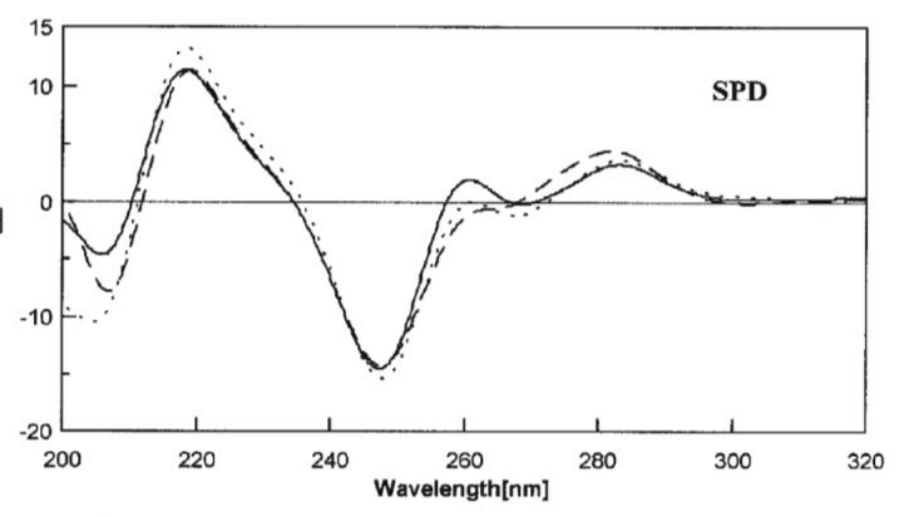

D

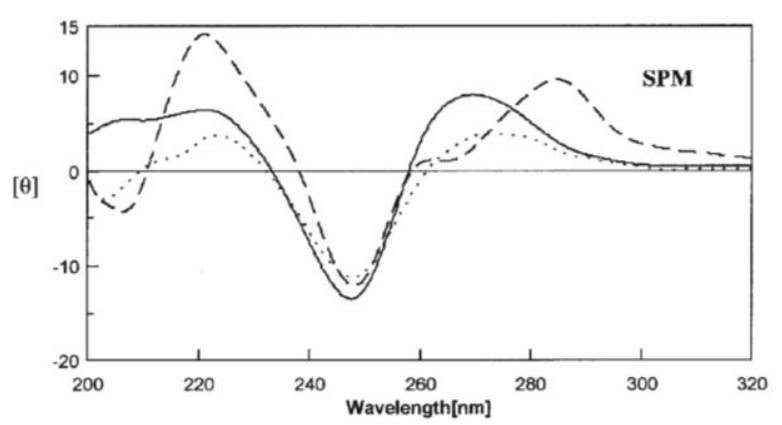


In Figure 8D, the DNA hairpins $\mathrm{H} 1$ and $\mathrm{H} 3$ with a $(\mathrm{dA} \cdot \mathrm{dT})_{\mathrm{n}}$ duplex stem have positive bands at $265 \mathrm{~nm}$ in the presence of spermine, which is typical of A-DNA [68]. The observation suggested that an intermediated conformation between B-DNA and A-DNA might be formed for H1 and H3 DNA.

\subsection{Neomycin}

Neomycin belongs to aminoglycoside class of antibiotics that contain two or more aminosugars connected by glycosidic bonds. It has been reported that neomycin could stabilize DNA, RNA, and hybrid triple helices while having little effect on the stabilization of DNA duplex [69]. The competition dialysis studies have shown the binding preference of neomycin toward A-form nucleic acids [70-72]. The selectivity of neomycin most likely originates from its shape complementarity with the A-form nucleic acids and triplex DNA harboring a narrower major groove [71]. In addition, neomycin has been known to bind different RNA structures and is capable of binding tightly to poly(A) [73]. Furthermore, several neomycin conjugates have also been designed and synthesized which performed different nucleic acids selectivity from neomycin. For example, dimeric neomycin-neomycin, neomycin-methidium (NM), and perylene-neomycin conjugates could selectively interact with AT-rich DNA duplex, DNA:RNA hybrid duplex, and human telomeric G-quadruplex, respectively [74-76]. Novel neomycin-Hoechst 33258 conjugate shows remarkable stabilization of DNA duplexes and destabilization of the DNA triplex [77]. BQQ-neomycin and pyrene-neomycin conjugates are more potent in stabilizing DNA helices than neomycin [78,79].

Arya's group has done several CD studies on these neomycin analogs to monitor drug-DNA interaction. They serially titrated neomycin into a solution of poly(A) and monitored by CD spectroscopy from $300 \mathrm{~nm}$ to $200 \mathrm{~nm}$ and the result indicated a binding ratio of one neomycin to 10 adenine bases [73]. CD titrations of the oligomer triplex showed an apparent binding site of 2.2 neomycin/triplex or $\sim 6$ base triplets/neomycin [80]. The $\mathrm{CD}$ titration studies of dimeric neomycin-neomycin conjugate also showed that depending on the structure/sequence of the duplex for AT-rich DNA duplexes, the conjugate binds to DNA with 10-12 base pairs/drug [74]. Moreover, CD experiment results of a series of neomycin conjugates showed that increasing concentration of NM to the DNA:RNA hybrid would result in a gradual increase in the melting temperature [75]. Furthermore, CD spectroscopy titrations of neomycin-Hoechst 33258-Pyrene Conjugate (NHP) showed a significant signal change in the poly $(\mathrm{dA}) \cdot \operatorname{poly}(\mathrm{dT})$ region, which is represented by a negative band at $248 \mathrm{~nm}$ and a positive band at $260 \mathrm{~nm}$ [81]. As the molar ratio of NHP:poly(dA) poly(dT) increased, there is an increasingly positive CD signal in the region of $360 \mathrm{~nm}$ [81]. It has also been reported that addition of perylene-neomycin conjugate to the G-quadruplex DNA solution resulted in the changes in the CD intensity of the 295 and $260 \mathrm{~nm}$ bands and a slight red shift in the band at $295 \mathrm{~nm}$, which suggests the interaction between the perylene-neomycin conjugate and G-quadruplex DNA [76]. Taken together, CD spectroscopy is an extremely useful tool to monitor specific DNA conformational changes by neomycin.

\subsection{Cisplatin}

Cisplatin is the first member of a class of platinum-containing anti-cancer drugs [82] which is used to treat various type of cancers. Cisplatin forms crosslink interaction with chromosomal DNA to 
interfere with cell division by mitosis and leads to programmed cell death. This interference activity contributes to Cisplatin's antitumor activity. Damage to DNA elicits DNA repair mechanisms and activates a programmed cell death process when the damage is too severe to be repaired. Recently, it has been reported that apoptosis would be induced by cisplatin on human colon cancer cells [83].

The guanine N7 position is a favorable site for platinum complexes. Platinum complexes interact with DNA duplex mostly by forming a 1,2-intrastrand cross-link between the N7 atoms of two adjacent guanine bases. According to X-ray crystallographic studies, cisplatin induces the duplex to bend toward the major groove, resulting in significant widening of the minor groove. CD spectroscopy has been used to obtain structural information about the global changes in DNA conformation induced by platinum complexes. It has been shown that the intensity of the positive CD band of B-DNA at $275 \mathrm{~nm}$ is increased as a consequence of DNA modification by the complexes containing the cis- $\left.\left[\mathrm{PtCl}_{2} \text { (amine }\right)_{2}\right]$ unit that reflects distortions in DNA of a nondenaturational nature $[84,85]$. In addition, the platinum complexes binding to human telomeric G-quadruplex were studied by CD spectroscopy. The non-modified human telomere sequence gives the characteristic CD signature with a maximum at $295 \mathrm{~nm}$ and a minimum at $260 \mathrm{~nm}$, and shows an antiparallel "basket" structure [86]. As the pagination level of human telomere sequence increases (up to four platinum atoms per sequence on average), pronounced reduction in the magnitude of the $\mathrm{CD}$ is observed along with an increasing shift in the wavelength. In addition, cisplatin caused more pronounced influence on the CD spectra of quadruplexes formed by the model human telomere sequence when compared with transplanting [86].

\subsection{The Effect of Polyamines on the Metal Derivative Complex of Aureolic Family Drug-DNA Complexes}

The paramagnetic metal ions $\mathrm{Fe}^{2+}, \mathrm{Co}^{2+}$, and $\mathrm{Cu}^{2+}$ with redo-cycling activities are required for several antibiotics to function properly, such as bleomycin and streptonigrin [37,87]. The positive charge (2+) and radii of these three transition metals are required for Chro-DNA dimeric complexes formation [88]. Spermine exists in the nucleus of cancer cells at millimolar concentrations, and has been reported to interact with transition metals to interfere with the activity of the aureolic family of drugs in cancer cells [89].

To monitor the effect of spermine on the structural integrity of the $\mathrm{Fe}^{2+}-\mathrm{Co}^{2+}$-, and $\mathrm{Cu}^{2+}$-containing dimeric Chro complexes upon DNA binding, the DNA-Chro complexes interaction was examined with increasing concentration of spermine $(0,1$, and $6 \mathrm{mM})$ [29]. As shown in Figure 9, the CD spectra of $\left[(\mathrm{Chro})_{2}-\mathrm{Co}^{2+}\right]$ and $\left[(\mathrm{Chro})_{2}-\mathrm{Fe}^{2+}\right]$ bound to the DNA duplex exhibited similar spectral features, with negative and positive peaks at 275 and $287 \mathrm{~nm}$, respectively, which are good evidence for an octahedral coordination. However, adding $6 \mathrm{mM}$ spermine to the DNA- $\left[(\mathrm{Chro})_{2}-\mathrm{Fe}^{2+}\right]$ complex reverted the $\mathrm{CD}$ spectrum to its original profile, suggesting spermine with this concentration is able to inhibit the formation of DNA-[(Chro $\left.)_{2}-\mathrm{Fe}^{2+}\right]$ complex (Figure 9A). Surprisingly, the same concentration of spermine is unable to interfere with the interaction between DNA and the $\left[(\mathrm{Chro})_{2}-\mathrm{Co}^{2+}\right]$ complex (Figure 9B). In the reaction between DNA and $\left[(\mathrm{Chro})_{2}-\mathrm{Co}^{2+}\right]$, conformation of DNA changed upon binding with $\left[(\mathrm{Chro})_{2}-\mathrm{Co}^{2+}\right]$ and the $\mathrm{CD}$ spectra flattened at 275 and $287 \mathrm{~nm}$ upon this interaction (Figure 9C). Low concentration of spermine $(1 \mathrm{mM})$ cause a slight decrease at $275 \mathrm{~nm}$ in the CD spectrum of the $\left[(\mathrm{Chro})_{2}-\mathrm{Cu}^{2+}\right]$-DNA complex, implying that an interaction occurs between them. When the concentration of spermine increased to $6 \mathrm{mM}$, the DNA- $\left[(\mathrm{Chro})_{2}-\mathrm{Cu}^{2+}\right]$ adduct was 
completely abolished, as demonstrated by an almost completely inverted CD spectrum (Figure 10C). These data provide strong evidence that spermine exhibits a strong affinity to $\mathrm{Fe}^{2+}$ and $\mathrm{Cu}^{2+}$ chelated by Chro, while it cannot disrupt the $\left[(\mathrm{Chro})_{2}-\mathrm{Co}^{2+}\right]$ complex even at a high concentration.

Figure 9. $\mathrm{CD}$ spectra of (A) $\left[(\mathrm{Chro})_{2}-\mathrm{Fe}^{2+}\right]-\mathrm{DNA},(\mathbf{B})\left[(\mathrm{Chro})_{2}-\mathrm{Co}^{2+}\right]-\mathrm{DNA}$, and (C) $\left[(\mathrm{Chro})_{2}-\mathrm{Cu}^{2+}\right]$-DNA in the various concentrations of spermine $(0,1$, and $6 \mathrm{mM})$. The drug concentration was $0.04 \mathrm{mM}$ in a buffer of $20 \mathrm{mM}$ Tris- $\mathrm{HCl}$ buffer ( $\mathrm{pH} 7.3$ ). The concentration of DNA was $20 \mu \mathrm{M}$. Synthetic hairpin DNA, 5'-TTGGCCAATGTTTGGCCAA-3', was used in the CD study (hairpin loop underlined). This figure was adapted from W.-J. Lu et al. [29] with permission.
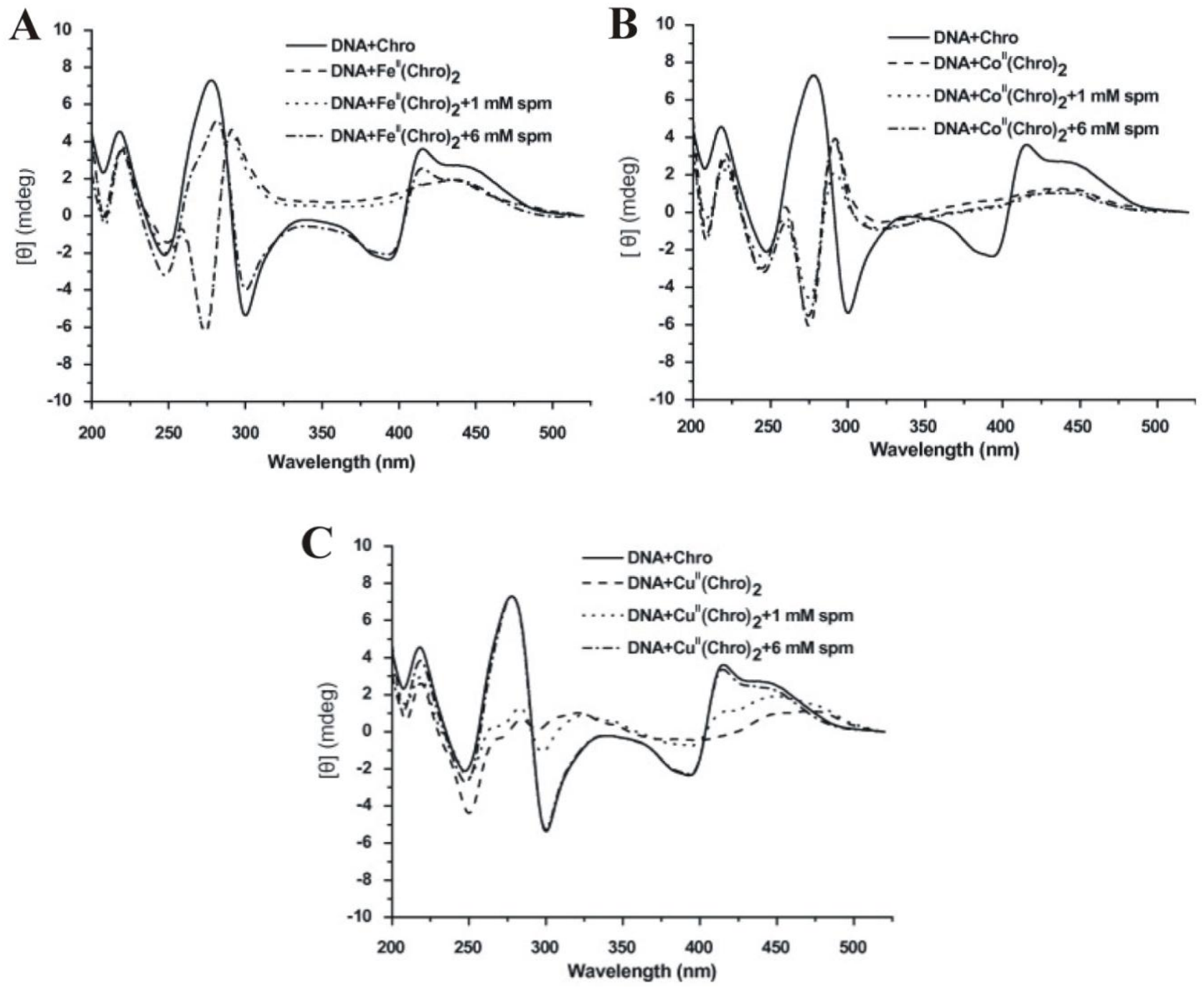
Figure 10. Comparison of the CD spectra of Mith-DNA, (Mith) $)_{2}$-metal ion(II)-DNA, and (Mith) $)_{2}$-metal ion(II)-DNA in the presence of $(\mathbf{A}, \mathbf{B})$ spermine $(\mathrm{spm})$ and $(\mathbf{C}, \mathbf{D})$ spermidine (sdm) at 1 and $6 \mathrm{mM}$ at $20{ }^{\circ} \mathrm{C}$. Metal ions(II) include $\mathrm{Fe}^{2+}$ and $\mathrm{Co}^{2+}$. The drug concentration was $0.04 \mathrm{mM}$ in a buffer of $20 \mathrm{mM}$ Tris- $\mathrm{HCl}(\mathrm{pH}$ 7.3). Reprinted with permission from ref. [90]. (Copyright 2009, American Chemical Society)
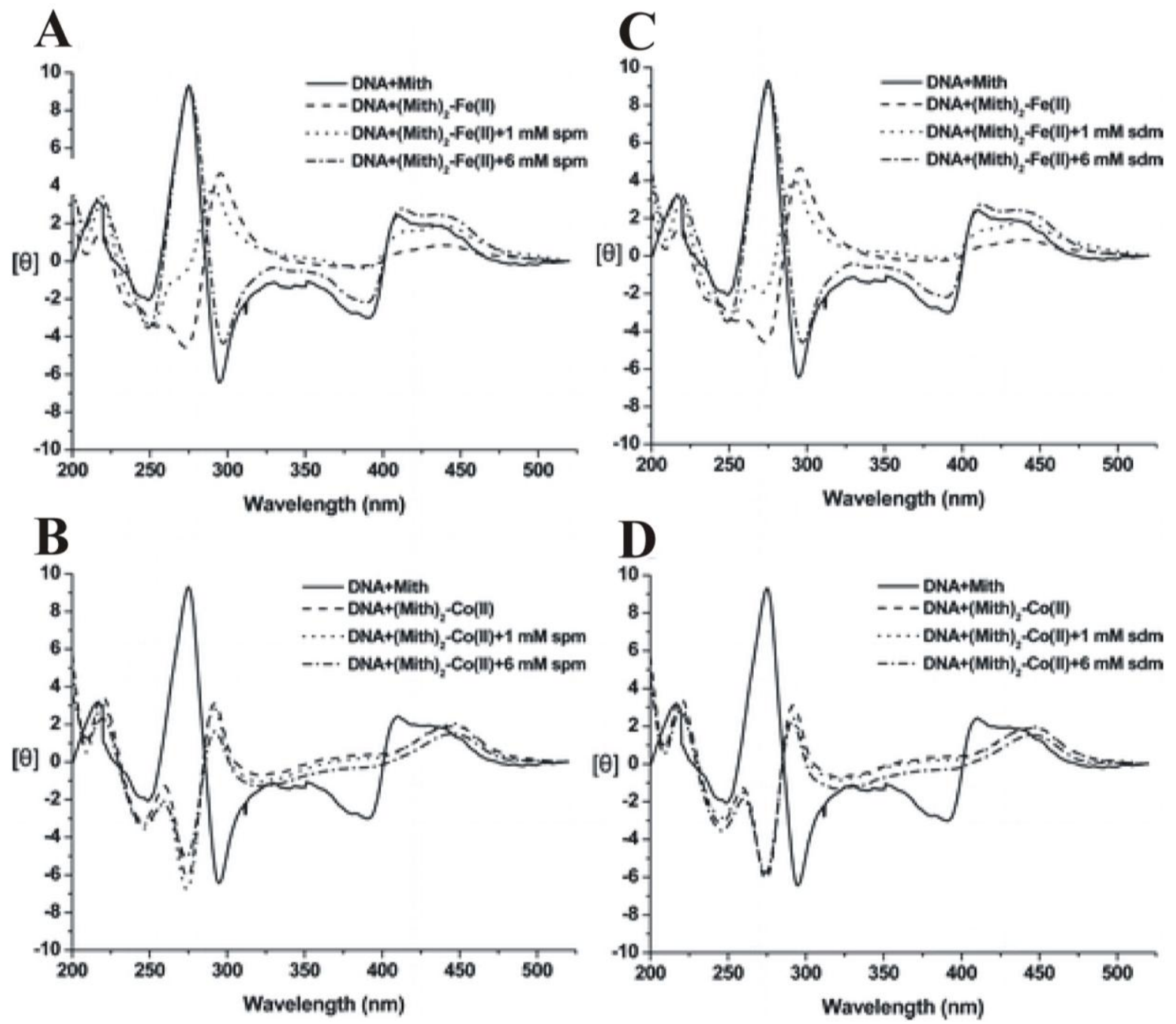

Moreover, the effect of polyamines on DNA interacting with [(Mith $\left.)_{2}-\mathrm{Fe}^{2+}\right]$ and $\left[(\mathrm{Mith})_{2}-\mathrm{Co}^{2+}\right]$ has also been studied using CD spectroscopy [90]. In the experiment, [( Mith $)_{2}-\mathrm{Fe}^{2+}$ ] and [( $\left.\mathrm{Mith}\right)_{2}-\mathrm{Co}^{2+}$ ] were incubated with hairpin DNA duplexes, allowing interaction to occur in the presence of increasing concentration of spermine or spermidine $(0,1$, and $6 \mathrm{mM})$. There is one Mith DNA-binding site (GGCC) on the tested DNA, 5'-TTGGCCAATGTTTGGCCAA-3', which also forms a hairpin duplex using $5^{\prime}$-TGT-3' as the loop region. In Figure 10, the solid line represents the CD spectrum of DNA and Mith monomer complex (DNA + Mith) and their interaction is not induced with the lack of metal ions. However, $\mathrm{Fe}^{2+}$ and $\mathrm{Co}^{2+}$ ions caused a dramatic change in $\mathrm{CD}$ spectral features at 287 and $275 \mathrm{~nm}$, which proved the ability of metal ions to mediate the interaction between Mith and DNA oligomer duplex. A low concentration of spermine or spermidine $(1 \mathrm{mM})$ caused minor intensity changes of [(Mith $\left.)_{2}-\mathrm{Fe}^{2+}\right]$-DNA at 275 and $287 \mathrm{~nm}$, suggesting the complex was partially disrupted. A high concentration of spermine or spermidine $(6 \mathrm{mM})$ was able to compete with $\mathrm{Fe}^{2+}$ for the 
interaction with the complex as the $\mathrm{CD}$ spectrum of [(Mith $\left.)_{2}-\mathrm{Fe}^{2+}\right]-\mathrm{DNA}$ was found to completely revert to the same profile as DNA + Mith. On the other hand, the presence of polyamines does not create a different $\mathrm{CD}$ spectra of the $\left[(\mathrm{Mith})_{2}-\mathrm{Co}^{2+}\right]$-DNA complexes. Thus, the copper ion in the $\left[(\mathrm{Mith})_{2}-\mathrm{Co}^{2+}\right]$-DNA complex is more resistant to the interaction competition of polyamine.

\section{Conclusion}

The purpose of this short review was to summarize the characteristics of CD spectra of important conformations of DNA and to demonstrate that CD spectroscopy is a useful way to monitor ligand-induced DNA conformational change. The recent development of CD-based technologies has made it possible to directly monitor the binding of ligands and compounds to a variety of DNA (Table 1). In these reports, CD spectroscopy is extremely useful in conformational studies of nucleic acids and for specific ligands that recognize DNA sequences and structures with high selectivity. More reliable studies, related to DNA-binding drugs, may emerge from ongoing experiments using CD spectrum technique.

Table 1. CD-based studies of biospecific interaction analysis between DNA-binding ligands and target DNA sequences.

\begin{tabular}{|c|c|c|}
\hline Drugs & Sequence Specificity & Target Sequence \\
\hline \multicolumn{3}{|l|}{ Anticancer drug } \\
\hline \multirow[t]{2}{*}{ Chromomycin $\mathrm{A}_{3}$} & G/C-rich sequence & $\mathrm{d}(\mathrm{TTGGCCAA})_{2}$ \\
\hline & $\mathrm{G} / \mathrm{C}$-rich sequence & $\mathrm{d}(\mathrm{TTGGCCAA})_{2}$ \\
\hline Mithramycin & G/C-rich sequence & $\mathrm{d}(\mathrm{TTGGCCAA})_{2}$ \\
\hline Blenomycin & G/C-rich sequence & d(CCCCAGCTGGGG) \\
\hline \multirow[t]{2}{*}{ Actinomycin D } & CTG triplet repeat sequence & $\mathrm{d}\left[(\mathrm{CAG})_{4} \cdot(\mathrm{CTG})_{16}\right]$ \\
\hline & telomeric G-quadruplex & $\mathrm{d}\left[\mathrm{GGG}(\mathrm{TTAGGG})_{3}\right]$ \\
\hline CC-1065 & AT-rich sequence & $\mathrm{d}(\mathrm{GAATT})$ \\
\hline Doxorubicin & telomeric G-quadruplex & $\mathrm{d}\left[\mathrm{GGG}(\mathrm{TTAGGG})_{3}\right]$ \\
\hline Sabarubicin & telomeric G-quadruplex & $\mathrm{d}\left[\mathrm{GGG}(\mathrm{TTAGGG})_{3}\right]$ \\
\hline Streptonigrin & little sequence specificity & $\mathrm{d}(\mathrm{GCATGC})_{2}$ \\
\hline cis-Platin & GC-rich sequence & $\operatorname{poly}(\mathrm{dG}) \cdot \operatorname{poly}(\mathrm{dC})$ \\
\hline SN-6999 & AT-rich sequence & $\operatorname{poly}(\mathrm{dA}) \cdot \operatorname{poly}(\mathrm{dT})$ \\
\hline SN-18071 & AT-rich sequence & $\operatorname{poly}(d A) \cdot \operatorname{poly}(d T)$ \\
\hline Rebeccam ycin & sequences containing GpT (ApC) & $\mathrm{d}(\mathrm{TGTTACGTT})_{2}$ \\
\hline & and $\mathrm{TpG}(\mathrm{CpA})$ steps & \\
\hline \multicolumn{3}{|l|}{ Antiviral drug } \\
\hline Lamivudine & little sequence specificity & Calf thymus DNA \\
\hline Valacyclovir & little sequence specificity & Calf thymus DNA \\
\hline isatin- $\beta$-thiosemicarbazone & little sequence specificity & Calf thymus DNA \\
\hline Tartrazine & little sequence specificity & Calf thymus DNA \\
\hline bis-netropsin & AT-rich sequence & $\operatorname{poly}(\mathrm{dA}) \cdot \operatorname{poly}(\mathrm{dT})$ \\
\hline Distamycin & AT-rich sequence & $\operatorname{poly}(\mathrm{dA}) \cdot \operatorname{poly}(\mathrm{dT})$ \\
\hline SN-7167 & AT-rich sequence & $\mathrm{d}(\mathrm{CGCGAATTCGCG})_{2}$ \\
\hline Berenil & AT-rich sequence & $\mathrm{d}\left(\mathrm{G}_{4} \mathrm{~A}_{4} \mathrm{G}_{4}-\left[\mathrm{T}_{4}\right]^{*}-\mathrm{C}_{4} \mathrm{~T}_{4} \mathrm{C}_{4}-\left[\mathrm{T}_{4}\right]^{*}-\mathrm{G}_{4} \mathrm{~T}_{4} \mathrm{G}_{4}\right)$ \\
\hline
\end{tabular}


Table 1. Cont.

\begin{tabular}{|c|c|c|}
\hline Antimicrobial drug & & \\
\hline Neomycin & A-form nucleic acids & 16S A-site rRNA \\
\hline Neomycin dimer & AT-rich sequence & $\mathrm{d}\left[5^{\prime}-\mathrm{A}_{12}-\mathrm{X}-\mathrm{T}_{12}-3^{\prime}\right]$ \\
\hline NHP & AT-rich sequence & $\operatorname{poly}(\mathrm{dA}) \cdot \operatorname{poly}(\mathrm{dT})$ \\
\hline NM & DNA:RNA hybrids & $\operatorname{poly}(\mathrm{dA}) \cdot \operatorname{poly}(\mathrm{rU})$ \\
\hline perylene-neomycin conjugate & G-quadruplex DNA & $5^{\prime}-\mathrm{d}\left[\mathrm{AG}_{3}\left(\mathrm{~T}_{2} \mathrm{AG}_{3}\right)_{3}\right]$ \\
\hline Mitomycin C & GC-rich sequence & $\operatorname{poly}(\mathrm{dG}) \cdot \operatorname{poly}(\mathrm{dC})$ \\
\hline Phenanthrolin & little sequence specificity & Calf thymus DNA \\
\hline Nogalamycin & little sequence specificity & Calf thymus DNA \\
\hline Enrofloxacin & little sequence specificity & Calf thymus DNA \\
\hline Neocarzinostatin & sequence-specific bulged DNA & \\
\hline \multicolumn{3}{|l|}{ Others } \\
\hline \multirow[t]{2}{*}{ Polyamine } & Major groove of GC-rich duplexes & $\operatorname{poly}(\mathrm{dG}) \cdot \operatorname{poly}(\mathrm{dC})$ \\
\hline & Minor groove of AT-rich duplexes & $\operatorname{poly}(\mathrm{dA}) \cdot \operatorname{poly}(\mathrm{dT})$ \\
\hline Pentamidine & AT-rich sequence & $\operatorname{poly}(\mathrm{dA}) \cdot \operatorname{poly}(\mathrm{dT})$ \\
\hline
\end{tabular}

$*\left[\mathrm{~T}_{4}\right]$ represents a stretch of four thymine residues.

\section{Acknowledgments}

This work was supported by NSC grants 100-2113-M-005-004-MY3 of M.-H. Hou.

\section{References}

1. Woody, R.W. Circular dichroism. Meth. Enzymology 1995, 246, 34-71.

2. Lewis, D.G.; Johnson, W.C., Jr. Circular dichroism of DNA in the vacuum ultraviolet. J. Mol. Biol. 1974, 86, 91-96.

3. Holm, A.I.; Nielsen, L.M.; Hoffmann, S.V.; Nielsen, S.B. Vacuum-ultraviolet circular dichroism spectroscopy of DNA: A valuable tool to elucidate topology and electronic coupling in DNA. Phys. Chem. Chem. Phys. 2010, 12, 9581-996.

4. Matsuo, K.; Yonehara, R.; Gekko, K. Secondary-structure analysis of proteins by vacuum-ultraviolet circular dichroism spectroscopy. J. Biochem. 2004, 135, 405-411.

5. Sreerama, N.; Venyaminov, S.Y.; Woody, R.W. Estimation of protein secondary structure from circular dichroism spectra: Inclusion of denatured proteins with native proteins in the analysis. Anal. Biochem. 2000, 287, 243-251.

6. Porumb, H.; Monnot, M.; Fermandjian, S. Circular dichroism signatures of features simultaneously present in structured guanine-rich oligonucleotides: A combined spectroscopic and electrophoretic approach. Electrophoresis 2002, 23, 1013-1020.

7. Zhou, J.; Yuan, G. Specific recognition of human telomeric G-quadruplex DNA with small molecules and the conformational analysis by ESI mass spectrometry and circular dichroism spectropolarimetry. Chemistry 2007, 13, 5018-5023.

8. Andrushchenko, V.; Bour, P. Applications of the Cartesian coordinate tensor transfer technique in the simulations of vibrational circular dichroism spectra of oligonucleotides. Chirality 2010, 22, E96-E114. 
9. Daura, X.; Bakowies, D.; Seebach, D.; Fleischhauer, J.; van Gunsteren, W.F.; Kruger, P. Circular dichroism spectra of beta-peptides: Sensitivity to molecular structure and effects of motional averaging. Eur. Biophys. J. 2003, 32, 661-670.

10. Kypr, J.; Kejnovska, I.; Renciuk, D.; Vorlickova, M. Circular dichroism and conformational polymorphism of DNA. Nucleic Acids Res. 2009, 37, 1713-1725.

11. Kankia, B.I.; Buckin, V.; Bloomfield, V.A. Hexamminecobalt(III)-induced condensation of calf thymus DNA: Circular dichroism and hydration measurements. Nucleic Acids Res. 2001, 29, 2795-2801.

12. Maestre, M.F. Circular dichroism of DNA films: Reversibility studies. J. Mol. Biol. 1970, 52, 543-556.

13. Boer, D.R.; Canals, A.; Coll, M. DNA-binding drugs caught in action: The latest 3D pictures of drug-DNA complexes. Dalton Trans. 2009, No. 3, 399-414.

14. Palchaudhuri, R.; Hergenrother, P.J. DNA as a target for anticancer compounds: Methods to determine the mode of binding and the mechanism of action. Curr. Opin. Biotechnol. 2007, 18, 497-503.

15. Watson, J.D.; Crick, F.H. Molecular structure of nucleic acids; a structure for deoxyribose nucleic acid. Nature 1953, 171, 737-738.

16. Nelson, H.C.; Finch, J.T.; Luisi, B.F.; Klug, A. The structure of an oligo(dA)·oligo(dT) tract and its biological implications. Nature 1987, 330, 221-226.

17. Alexeev, D.G.; Lipanov, A.A.; Skuratovskii, I. Poly(dA)·poly(dT) is a B-type double helix with a distinctively narrow minor groove. Nature 1987, 325, 821-823.

18. Trantirek, L.; Stefl, R.; Vorlickova, M.; Koca, J.; Sklenar, V.; Kypr, J. An A-type double helix of DNA having B-type puckering of the deoxyribose rings. J. Mol. Biol. 2000, 297, 907-922.

19. Ivanov, V.I.; Minchenkova, L.E.; Minyat, E.E.; Frank-Kamenetskii, M.D.; Schyolkina, A.K. The B to A transition of DNA in solution. J. Mol. Biol. 1974, 87, 817-833.

20. Stefl, R.; Trantirek, L.; Vorlickova, M.; Koca, J.; Sklenar, V.; Kypr, J. A-like guanine-guanine stacking in the aqueous DNA duplex of d(GGGGCCCC). J. Mol. Biol. 2001, 307, 513-524.

21. Jaworski, A.; Hsieh, W.T.; Blaho, J.A.; Larson, J.E.; Wells, R.D. Left-handed DNA in vivo. Science 1987, 238, 773-777.

22. Lezius, A.G.; Gottschalk, E.M. A reversible cooperative conformational change of a synthetic DNA under the influence of high salt concentrations. Hoppe-Seylers Z. Physiol. Chem. 1970, 351, 413-416.

23. Ivanov, V.I.; Minyat, E.E. The transitions between left- and right-handed forms of poly(dG-dC). Nucleic Acids Res. 1981, 9, 4783-4798.

24. Balagurumoorthy, P.; Brahmachari, S.K.; Mohanty, D.; Bansal, M.; Sasisekharan, V. Hairpin and parallel quartet structures for telomeric sequences. Nucleic Acids Res. 1992, 20, 4061-4067.

25. Dapic, V.; Abdomerovic, V.; Marrington, R.; Peberdy, J.; Rodger, A.; Trent, J.O.; Bates, P.J. Biophysical and biological properties of quadruplex oligodeoxyribonucleotides. Nucleic Acids Res. 2003, 31, 2097-2107.

26. Paramasivan, S.; Rujan, I.; Bolton, P.H. Circular dichroism of quadruplex DNAs: Applications to structure, cation effects and ligand binding. Methods 2007, 43, 324-331. 
27. Foley, J.M. The size-distance relation and intrinsic geometry of visual space: Implications for processing. Vision Res. 1972, 12, 323-332.

28. Du Priest, R.W., Jr.; Fletcher, W.S. Chemotherapy of testicular germinal tumors. Oncology 1973, $28,147-163$.

29. Lu, W.J.; Wang, H.M.; Yuann, J.M.; Huang, C.Y.; Hou, M.H. The impact of spermine competition on the efficacy of DNA-binding $\mathrm{Fe}(\mathrm{II}), \mathrm{Co}(\mathrm{II})$, and $\mathrm{Cu}$ (II) complexes of dimeric chromomycin A(3). J. Inorg. Biochem. 2009, 103, 1626-1633.

30. Altaner, C.; Ban, J.; Zajac, V.; Rossler, H.; Rosenthal, S.; Kettmann, R.; Burny, A. Isolation and characterization of cell clones producing various amounts of bovine leukosis virus. Folia Biol. (Praha) 1985, 31, 107-114.

31. Chakrabarti, S.; Aich, P.; Sarker, D.; Bhattacharyya, D.; Dasgupta, D. Role of $\mathrm{Mg}^{2+}$ in the interaction of anticancer antibiotic, chromomycin A3 with DNA: Does neutral antibiotic bind DNA in absence of the metal ion? J. Biomol. Struct. Dyn. 2000, 18, 209-218.

32. Aich, P.; Sen, R.; Dasgupta, D. Role of magnesium ion in the interaction between chromomycin A3 and DNA: Binding of chromomycin A3- $\mathrm{Mg}^{2+}$ complexes with DNA. Biochemistry 1992, 31, 2988-2997.

33. Devi, P.G.; Pal, S.; Banerjee, R.; Dasgupta, D. Association of antitumor antibiotics, mithramycin and chromomycin, with $\mathrm{Zn}(\mathrm{II})$. J. Inorg. Biochem. 2007, 101, 127-137.

34. Hou, M.H.; Lu, W.J.; Lin, H.Y.; Yuann, J.M. Studies of sequence-specific DNA binding, DNA cleavage, and topoisomerase I inhibition by the dimeric chromomycin A3 complexed with $\mathrm{Fe}(\mathrm{II})$. Biochemistry 2008, 47, 5493-5502.

35. Slavik, M.; Carter, S.K. Chromomycin A3, mithramycin, and olivomycin: Antitumor antibiotics of related structure. Adv. Pharmacol. Chemother. 1975, 12, 1-30.

36. Goldberg, I.H.; Friedman, P.A. Antibiotics and nucleic acids. Annu. Rev. Biochem. 1971, 40, 775-810.

37. Yang, X.L.; Wang, A.H. Structural studies of atom-specific anticancer drugs acting on DNA. Pharmacol. Ther. 1999, 83, 181-215.

38. Kennedy, B.J. Mithramycin therapy in testicular cancer. J. Urol. 1972, 107, 429-432.

39. Elias, E.G.; Evans, J.T. Mithramycin in the treatment of Paget's disease of bone. J. Bone Joint Surg. Am. 1972, 54, 1730-1736.

40. Fibach, E.; Bianchi, N.; Borgatti, M.; Prus, E.; Gambari, R. Mithramycin induces fetal hemoglobin production in normal and thalassemic human erythroid precursor cells. Blood 2003, 102, 1276-1281.

41. Hou, M.H.; Wang, A.H. Mithramycin forms a stable dimeric complex by chelating with $\mathrm{Fe}(\mathrm{II})$ : DNA-interacting characteristics, cellular permeation and cytotoxicity. Nucleic Acids Res. 2005, 33, 1352-1361.

42. Sobell, H.M.; Jain, S.C. Stereochemistry of actinomycin binding to DNA. II. Detailed molecular model of actinomycin-DNA complex and its implications. J. Mol. Biol. 1972, 68, 21-34.

43. Kamitori, S.; Takusagawa, F. Crystal structure of the 2:1 complex between d(GAAGCTTC) and the anticancer drug actinomycin D. J. Mol. Biol. 1992, 225, 445-456. 
44. Hurwitz, J.; Furth, J.J.; Malamy, M.; Alexander, M. The role of deoxyribonucleic acid in ribonucleic acid synthesis. III. The inhibition of the enzymatic synthesis of ribonucleic acid and deoxyribonucleic acid by actinomycin D and proflavin. Proc. Natl. Acad. Sci. USA 1962, 48, 1222-1230.

45. Aivasashvilli, V.A.; Beabealashvilli, R.S. Sequence-specific inhibition of RNA elongation by actinomycin D. FEBS Lett. 1983, 160, 124-128.

46. Chen, F.M. Kinetic and equilibrium binding studies of actinomycin D with some d(TGCA)-containing dodecamers. Biochemistry 1988, 27, 1843-1848.

47. Margolis, R.L.; O’Hearn, E.; Rosenblatt, A.; Willour, V.; Holmes, S.E.; Franz, M.L.; Callahan, C.; Hwang, H.S.; Troncoso, J.C.; Ross, C.A. A disorder similar to Huntington's disease is associated with a novel CAG repeat expansion. Ann. Neurol. 2001, 50, 373-380.

48. Seznec, H.; Agbulut, O.; Sergeant, N.; Savouret, C.; Ghestem, A.; Tabti, N.; Willer, J.C.; Ourth, L.; Duros, C.; Brisson, E.; et al. Mice transgenic for the human myotonic dystrophy region with expanded CTG repeats display muscular and brain abnormalities. Hum. Mol. Genet. 2001, 10, 2717-2726.

49. Paulson, H.L.; Fischbeck, K.H. Trinucleotide repeats in neurogenetic disorders. Annu. Rev. Neurosci. 1996, 19, 79-107.

50. Hou, M.H.; Robinson, H.; Gao, Y.G.; Wang, A.H. Crystal structure of actinomycin D bound to the CTG triplet repeat sequences linked to neurological diseases. Nucleic Acids Res. 2002, 30, 4910-4917.

51. Hou, M.H.; Lin, S.B.; Yuann, J.M.; Lin, W.C.; Wang, A.H.; Kan Ls, L. Effects of polyamines on the thermal stability and formation kinetics of DNA duplexes with abnormal structure. Nucleic Acids Res. 2001, 29, 5121-5128.

52. N'Soukpoe-Kossi, C.N.; Ouameur, A.A.; Thomas, T.; Shirahata, A.; Thomas, T.J.; Tajmir-Riahi, H.A. DNA interaction with antitumor polyamine analogues: A comparison with biogenic polyamines. Biomacromolecules 2008, 9, 2712-2718.

53. Ouameur, A.A.; Bourassa, P.; Tajmir-Riahi, H.A. Probing tRNA interaction with biogenic polyamines. RNA 2010, 16, 1968-1979.

54. N’Soukpoe-Kossi, C.N.; Ahmed Ouameur, A.; Thomas, T.; Thomas, T.J.; Tajmir-Riahi, H.A. Interaction of tRNA with antitumor polyamine analogues. Biochem. Cell Biol. 2009, 87, 621-630.

55. Marty, R.; N'Soukpoe-Kossi, C.N.; Charbonneau, D.M.; Kreplak, L.; Tajmir-Riahi, H.A. Structural characterization of cationic lipid-tRNA complexes. Nucleic Acids Res. 2009, 37, 5197-5207.

56. Igarashi, K.; Kashiwagi, K. Polyamines: Mysterious modulators of cellular functions. Biochem. Biophys. Res. Commun. 2000, 271, 559-564.

57. Patel, A.R.; Wang, J.Y. Polyamine depletion is associated with an increase in JunD/AP-1 activity in small intestinal crypt cells. Am. J. Physiol. 1999, 276, G441-G450.

58. Panagiotidis, C.A.; Artandi, S.; Calame, K.; Silverstein, S.J. Polyamines alter sequence-specific DNA-protein interactions. Nucleic Acids Res. 1995, 23, 1800-1809.

59. Frugier, M.; Florentz, C.; Hosseini, M.W.; Lehn, J.M.; Giege, R. Synthetic polyamines stimulate in vitro transcription by T7 RNA polymerase. Nucleic Acids Res. 1994, 22, 2784-2790. 
60. Wang, Y.; Devereux, W.; Stewart, T.M.; Casero, R.A., Jr. Characterization of the interaction between the transcription factors human polyamine modulated factor (PMF-1) and NF-E2-related factor 2 (Nrf-2) in the transcriptional regulation of the spermidine/spermine N1-acetyltransferase (SSAT) gene. Biochem. J. 2001, 355, 45-49.

61. Westerhoff, H.V.; O’Dea, M.H.; Maxwell, A.; Gellert, M. DNA supercoiling by DNA gyrase. A static head analysis. Cell Biophys. 1988, 12, 157-181.

62. Pommier, Y.; Kerrigan, D.; Kohn, K. Topological complexes between DNA and topoisomerase II and effects of polyamines. Biochemistry 1989, 28, 995-1002.

63. Gao, Y.G.; Robinson, H.; Wang, A.H. High-resolution A-DNA crystal structures of d(AGGGGCCCCT). An A-DNA model of poly(dG).poly(dC). Eur. J. Biochem. 1999, 261, 413-420.

64. Ohishi, H.; Terasoma, N.; Nakanishi, I.; van der Marel, G.; van Boom, J.H.; Rich, A.; Wang, A.H.; Hakoshima, T.; Tomita, K. Interaction between left-handed Z-DNA and polyamine-3. The crystal structure of the $\mathrm{d}(\mathrm{CG})_{3}$ and thermospermine complex. FEBS Lett. 1996, 398, 291-296.

65. Ouameur, A.A.; Tajmir-Riahi, H.A. Structural analysis of DNA interactions with biogenic polyamines and cobalt(III)hexamine studied by Fourier transform infrared and capillary electrophoresis. J. Biol. Chem. 2004, 279, 42041-42054.

66. Marky, L.A.; Snyder, J.G.; Breslauer, K.J. Calorimetric and spectroscopic investigation of drug_DNA interactions: II. Dipyrandium binding to poly d(AT). Nucleic Acids Res. 1983, 11, 5701-5715.

67. Antony, T.; Thomas, T.; Shirahata, A.; Thomas, T.J. Selectivity of polyamines on the stability of RNA-DNA hybrids containing phosphodiester and phosphorothioate oligodeoxyribonucleotides. Biochemistry 1999, 38, 10775-10784.

68. Gyi, J.I.; Conn, G.L.; Lane, A.N.; Brown, T. Comparison of the thermodynamic stabilities and solution conformations of DNA.RNA hybrids containing purine-rich and pyrimidine-rich strands with DNA and RNA duplexes. Biochemistry 1996, 35, 12538-12548.

69. Arya, D.P.; Coffee, R.L., Jr.; Willis, B.; Abramovitch, A.I. Aminoglycoside-nucleic acid interactions: Remarkable stabilization of DNA and RNA triple helices by neomycin. J. Am. Chem. Soc. 2001, 123, 5385-5395.

70. Arya, D.P.; Xue, L.; Willis, B. Aminoglycoside (neomycin) preference is for A-form nucleic acids, not just RNA: Results from a competition dialysis study. J. Am. Chem. Soc. 2003, 125, 10148-10149.

71. Hamilton, P.L.; Arya, D.P. Natural product DNA major groove binders. Nat. Prod. Rep. 2012, 29, 134-143.

72. Xi, H.; Davis, E.; Ranjan, N.; Xue, L.; Hyde-Volpe, D.; Arya, D.P. Thermodynamics of nucleic acid "shape readout" by an aminosugar. Biochemistry 2011, 50, 9088-9113.

73. Xi, H.; Gray, D.; Kumar, S.; Arya, D.P. Molecular recognition of single-stranded RNA: Neomycin binding to poly(A). FEBS Lett. 2009, 583, 2269-2275.

74. Kumar, S.; Xue, L.; Arya, D.P. Neomycin-neomycin dimer: An all-carbohydrate scaffold with high affinity for AT-rich DNA duplexes. J. Am. Chem. Soc. 2011, 133, 7361-7375.

75. Shaw, N.N.; Xi, H.; Arya, D.P. Molecular recognition of a DNA:RNA hybrid: Sub-nanomolar binding by a neomycin-methidium conjugate. Bioorg. Med. Chem. Lett. 2008, 18, 4142-4145. 
76. Xue, L.; Ranjan, N.; Arya, D.P. Synthesis and spectroscopic studies of the aminoglycoside (neomycin)-perylene conjugate binding to human telomeric DNA. Biochemistry 2011, 50, 2838-2849.

77. Willis, B.; Arya, D.P. Recognition of B-DNA by neomycin-Hoechst 33258 conjugates. Biochemistry 2006, 45, 10217-10232.

78. Arya, D.P.; Xue, L.; Tennant, P. Combining the best in triplex recognition: Synthesis and nucleic acid binding of a BQQ-neomycin conjugate. J. Am. Chem. Soc. 2003, 125, 8070-8071.

79. Xue, L.; Charles, I.; Arya, D.P. Pyrene-neomycin conjugate: Dual recognition of a DNA triple helix. Chem. Commun. (Camb) 2002, 1, 70-71.

80. Xi, H.; Kumar, S.; Dosen-Micovic, L.; Arya, D.P. Calorimetric and spectroscopic studies of aminoglycoside binding to AT-rich DNA triple helices. Biochimie 2010, 92, 514-529.

81. Willis, B.; Arya, D.P. Triple recognition of B-DNA by a neomycin-Hoechst 33258-pyrene conjugate. Biochemistry 2010, 49, 452-469.

82. Rosenberg, B.; Vancamp, L.; Krigas, T. Inhibition of cell division in escherichia coli by electrolysis products from a platinum electrode. Nature 1965, 205, 698-699.

83. Pruefer, F.G.; Lizarraga, F.; Maldonado, V.; Melendez-Zajgla, J. Participation of Omi Htra2 serine-protease activity in the apoptosis induced by cisplatin on SW480 colon cancer cells. J. Chemother. 2008, 20, 348-354.

84. Vrana, O.; Brabec, V.; Kleinwachter, V. Polarographic studies on the conformation of some platinum complexes: Relations to anti-tumour activity. Anticancer Drug Des. 1986, 1, 95-109.

85. Brabec, V.; Kleinwachter, V.; Butour, J.L.; Johnson, N.P. Biophysical studies of the modification of DNA by antitumour platinum coordination complexes. Biophys. Chem. 1990, 35, 129-141.

86. Heringova, P.; Kasparkova, J.; Brabec, V. DNA adducts of antitumor cisplatin preclude telomeric sequences from forming G quadruplexes. J. Biol. Inorg. Chem. 2009, 14, 959-968.

87. Ming, L.J. Structure and function of "metalloantibiotics". Med. Res. Rev. 2003, 23, 697-762.

88. Itzhaki, L.; Weinberger, S.; Livnah, N.; Berman, E. A unique binding cavity for divalent cations in the DNA-metal-chromomycin A3 complex. Biopolymers 1990, 29, 481-489.

89. Gaboriau, F.; Kreder, A.; Clavreul, N.; Moulinoux, J.P.; Delcros, J.G.; Lescoat, G. Polyamine modulation of iron uptake in CHO cells. Biochem. Pharmacol. 2004, 67, 1629-1637.

90. Hou, M.H.; Lu, W.J.; Huang, C.Y.; Fan, R.J.; Yuann, J.M. Effects of polyamines on the DNA-reactive properties of dimeric mithramycin complexed with cobalt(II): Implications for anticancer therapy. Biochemistry 2009, 48, 4691-4698.

(C) 2012 by the authors; licensee MDPI, Basel, Switzerland. This article is an open access article distributed under the terms and conditions of the Creative Commons Attribution license (http://creativecommons.org/licenses/by/3.0/). 